\title{
Effect of breastfeeding on common pediatric infections: a 5-year prospective cohort study
}

\author{
Cüneyt Ardıç, M.D. ${ }^{a}$ and Erdinç Yavuz, M.D. ${ }^{b}$
}

\begin{abstract}
Introduction. The studies conducted revealed that breastfeeding duration has a reducing effect on common infectious diseases in the children during breastfeeding period.

Objective. The aim of the present study was to address the association between breastfeeding duration and common infectious diseases in the children until 5 years of age to show long-term protective effects of the breast milk.

Population and Methods. The study included 411 infants who were born in Rize (Turkey) between January 2011 and December 2011. The present prospective-cohort study lasted for 5 years and 11 interviews were conducted with each mother of the infants during this period. The infants were divided into two groups as those who were breastfed more and less than 12 months and the association between breastfeeding and infections such as acute otitis media, acute gastroenteritis, acute respiratory tract infections and acute urinary system infections was investigated.

Results. Of 270 infants 193(71.5\%) werebreastfed longer than 12 months and $77(28.5 \%)$ were breastfed less than 12 months. Infants in the first group had less acute otitis media and acute gastroenteritis ( $\mathrm{n}=77,28.52 \%)$ when compared with the infants breastfed less than 12 months during 5 -year period ( $\mathrm{p}<0.05$ ).

Conclusions. The present study detected that breastfeeding duration longer than 12 months significantly reduces the common childhood infections such as otitis media and gastroenteritis during the first 5 years of life.

Key words: Breast milk, breastfeeding, pediatrics, infection.
\end{abstract}

http:/ / dx.doi.org/10.5546/ aap.2018.eng.126

To cite: Ardıç C, Yavuz E. Effect of breastfeeding on common pediatric infections: a 5-year prospective cohort study. Arch Argent Pediatr 2018;116(2):126-132.

\section{INTRODUCTION}

Breast milk is the most valuable food for newborns and infants. ${ }^{1}$ The breast milk is an excellent nutritional source for the baby and it also contains antibodies, cytokines, growth factors, antimicrobial substances and specific immunity cells. ${ }^{2}$

World Health Organization (WHO) and United Nations
International Children's Emergency Fund (UNICEF) make a huge effort to widespread breastfeeding all over the world. WHO and UNICEF recommend to breastfeed the babies for the first six months of life, to start supplementary food by seventh month and to continue breastfeeding until 2 years of age. ${ }^{3}$

Improvement of the immune system and protective effects against infections continue throughout breastfeeding period. ${ }^{4}$ It is suggested that the influences of breast milk on the infant's immune system may continue even after the breastfeeding period, as breastfeeding provides passive immunity as well as maturation of the immune system in the long run. ${ }^{5,6}$

The positive effect of breastfeeding for protection against infectious diseases may be explained through many components such as promoting mucosal maturation, balancing the intestinal microflora and stimulation of the immune system. ${ }^{7,8}$

In developing countries like Turkey the most significant causes for hospitalization of the children below 5 years of age are respiratory system infections and gastroeneteritis..$^{9-11}$ Newborns are particularly vulnerable against the infections acquired through respiratory system and gastrointestinal mucosa; simple infections may easily spread. ${ }^{12}$ Protective effects of breastfeeding on these infectious diseases during infancy are wellknown, but long term effects even after infancy were rarely investigated. ${ }^{13}$

There area limited number of studies on long-term influences of breastfeeding on common infections during childhood in the literature. This present study is the first prospective-cohort conducted in 
Turkey investigating the relationship between breastfeeding duration of the children and acute otitis, acute gastroenteritis, urinary system infections and acute respiratory tract infections.

The aim of the present study was to address the association between breastfeeding duration and common infectious diseases in the children until 5 years of age to show long-term protective effects of the breast milk.

\section{MATERIALS AND METHODS The sample}

This prospective-cohort study included 411 children who were born in Rize, Turkey between January 2011 and December 2011 and had regular monitoring by family practitioners. Approval of the committee of ethics was obtained by Ethical Board of Faculty of Medicine in Recep Tayyip Erdogan University. The study was started after informed consent forms were obtained from mothers of all participants and continued until all children became 60 months old.

\section{Study design}

The mothers and the infants enrolled into the study were those who were registered to family practitioners working in Rize. Family practitioner records of the infants enrolled were based on, not the hospital records. Such infants and the mothers were followed on regular intervals for 5 years by the same family physicians.

All infants were monitored in accordance with infant and child monitoring protocol for family practitioners regulated by Turkish Ministry of Health for 5 years. Such protocol regulates monitoring of the infants in family health centers at months $1,3,7,9,12,18,24,30,36,48,60$.

\section{Inclusion criteria}

The infants who were born between January 2011 and December 2011 and registered in family practice system in Rize and their mothers who have given consent for participation and whose pregnancies follow-ups were performed by the same family practitioners.

\section{Exclusion criteria}

The infants with congenital immune system deficiency, congenital cardiac disease, diagnosed by asthma before 5 years of age, with low birth weight below 2,500 grams, diagnosed with early rupture of the membranes and the infants who have not come to any of the follow-up visits before 5 years of age.
Exclusion cause of this babies was their tendency to infections because of their insufficient immune systems. Children diagnosed with asthma were excluded from the study because of their tendency to some bacterial infections, and also very high incidence of asthmatic crisis and concurrent infection. ${ }^{14,15}$

\section{Follow up}

Mothers of the babies were asked about feeding status, breastfeeding status and onset to supplementary food during each monitoring. According to the answers obtained, the children were divided into two groups as babies who have started supplementary food before 6 months and those who were only breastfed for 6 months (exclusive breastfeeding). Furthermore, the mothers were asked, "Do you continue to breastfeed your baby?" and according to the answers, the participants were divided into two groups as those who were breastfed for more and less than 12 months.

Mothers of all participants were told to keep records of all diagnoses on their children and these records were noted by physicians according to International Statistical Classification of Diseases and Related Health Problems (ICD10) code system to detect infection diagnoses of the children for five years. Table 1 shows these diagnoses under four main groups according to the aforesaid code system. Moreover, the diagnoses marked by the mothers during each monitoring visit in Family Health Center were also investigated through Electronic Health Record System (EHRS); diagnoses and the information provided by the mothers were matched.

\section{Statistical analysis}

The findings of the present research were analyzed through Statistical Package for Social Sciences (SPSS) for Windows 20.0 computer program. Evaluation of the data was conducted with descriptive statistical methods (average, median, standard deviation); furthermore, student $\mathrm{T}$ test was used to compare normal distribution variables whereas Mann-Whitney $U$ test to compare non-normal distribution variables.

Pearson's correlation was used to investigate the correlations between the variables. Statistical significance was defined at a level of $5 \%(\mathrm{p}<0.05)$.

\section{RESULTS}

The present study was started with 411 expectant mothers and completed with 
270 patients $(65.8 \%)$ after exclusion of two patients with Down syndrome, three patients with congenital heart disease, one patient with congenital immunoglobulin A (IgA) deficiency, eight infants with low birth weight $(<2,500 \mathrm{~g})$, three infants with premature rupture of the membranes, 15 patients with asthma and 109 infants who have not come to the monitoring visits regularly. (Figure 1)

Especially after 2008 where Turkey has commenced Family Practice System, a detailed information was provided to the public about importance of breastfeeding and benefits of the breast milk through the campaigns carried out by Turkish Ministry of Health. ${ }^{16}$ This also affected the present study and number of the infants who were never breastfed was limited with 17 babies $(6.29 \%)$.

Among the participant mothers, 157 (58.15\%) of them have only breastfed their babies during the first 6 months (exclusive breastfeeding); and 193 mothers $(71.48 \%)$ have breastfed their babies longer than 12 months.

Incidence for acute otitis media and acute gastroenteritis in the infants who were breastfed longer than 12 months were less than those who were breastfed less than 12 months $(p<0.05)$. Similarly, acute otitis media and acute gastroenteritis were detected significantly less in the infants who were exclusively breastfed during the first 6 months. (Table 2)

When relation between incidence of respiratory system infections and duration of breastfeeding was evaluated, babies who breastfed longer than 12 months had less infections than those breastfed shorter than 12 months but it didn't differ significantly $(p=0.059)$.

Number of the urinery system infections until 5 years between babies who breastfed longer than 12 months and breastfed shorter than 12 months were not significantly different $(\mathrm{p}=0.896)$.

Table 3 shows the association between sociodemographic characteristics of the mothers as well as the infants and breastfeeding period. Mean age of the mothers was $28.7( \pm 9.71) ; 45.56 \%$ of them were between 26-35 years of age range. Most of the mothers who have breastfed their babies at least for 12 months $(30.37 \%)$ were between 26 and 35 years of age. Majority of the participant mothers

TABLE 1. Classification of infection diseases analyzed by ICD-10

\begin{tabular}{|c|c|c|c|}
\hline $\begin{array}{l}\text { Acute urinary system } \\
\text { infections }\end{array}$ & $\begin{array}{l}\text { Respiratory } \\
\text { tract infections }\end{array}$ & $\begin{array}{c}\text { Acute } \\
\text { otitis media } \\
\end{array}$ & $\begin{array}{c}\text { Acute } \\
\text { gastroenteritis }\end{array}$ \\
\hline $\begin{array}{l}\text { N30.0 Acute cystitis } \\
\text { N30.8 Other cystitis } \\
\text { N30.9 Cystitis, } \\
\text { unspecified } \\
\text { N39.0 Urinary tract } \\
\text { infection, site not } \\
\text { specified }\end{array}$ & $\begin{array}{l}\text { J12 Viral pneumonia, not else } \\
\text { where classified } \\
\text { J13 Pneumonia due to } \\
\text { Streptococcus pneumoniae } \\
\text { J14 Pneumonia due to } \\
\text { Haemophilus influenzae } \\
\text { J15 Bacterial pneumonia, } \\
\text { not else where classified } \\
\text { J16 Pneumonia due to other infectious } \\
\text { organisms, not else where classified } \\
\text { J17 Pneumonia in diseases classified } \\
\text { else where } \\
\text { J18 Pneumonia, organis munspecified } \\
\text { J20 Acute bronchitis } \\
\text { J21 Acute bronchiolitis } \\
\text { J22 Unspecified acute lower } \\
\text { respiratory infection } \\
\text { J40 Bronchitis, not specified as } \\
\text { acute or chronic } \\
\text { J06 Acute upper respiratory infections } \\
\text { of multiple and unspecified sites } \\
\text { J04 Acute laryngitis and tracheitis } \\
\text { J39 Other diseases of upper } \\
\text { respiratory tract } \\
\text { J00 Acute nasopharyngitis } \\
\text { [common cold] } \\
\text { J01 Acute sinusitis } \\
\text { J02 Acute pharyngitis } \\
\text { J03 Acute tonsillitis }\end{array}$ & $\begin{array}{l}\text { H65 Nonsuppurative } \\
\text { otitis media } \\
\text { H66 Suppurative and } \\
\text { unspecified otitis media } \\
\text { H67 Otitis media in diseases } \\
\text { classified else where }\end{array}$ & $\begin{array}{l}\text { A09 Other gastroenteritis } \\
\text { and colitis of infectious } \\
\text { and unspecified origin } \\
\text { A08 Viral and other } \\
\text { specified intestinal } \\
\text { infections }\end{array}$ \\
\hline
\end{tabular}


$(136 ; 50.37 \%)$ were elementary school graduate and $10(3.70 \%)$ of them never breastfed their babies.

Among the participant mothers, 181 (67.04\%) had breastfeeding consultancy services whereas 136 mothers $(50.37 \%)$ who had consultancy services have breastfed their babies longer than 12 months. Twelve mothers $(4.44 \%)$ who had not received any consultancy never breastfed their babies.

Tobacco exposure was present for 54 participant babies $(20 \%)$ and four $(7.41 \%)$ of them were not breastfed at all. Number of siblings and daycare attendance of the participants, monthly income, sex of infants and attendance to day nursery were presented in Table 2.

\section{DISCUSSION}

Although there are a limited number of studies on effect of breast milk against infections, the present prospective-cohort study is the first conducted in Turkey.

Among the infants who were monitored at regular intervals and whose diseases records were taken for 5 years, those who were breastfed for 12 months and more have less acute otitis media and acute gastroenteritis than those who were breastfed for less than 12 months $(\mathrm{p}<0.05)$. Furthermore, the babies who were breastfed exclusively during first 6 months developed both diseases less than those who started additional food before 6 months of age.

FIGURE 1: Flow diagram for selection of participants

\begin{tabular}{|l|l|}
\hline $\begin{array}{l}\text { Infants included in the study } \\
(n=411)\end{array}$ & $\begin{array}{l}\text { Infants excluded (numbers and reasons) } \\
\text { Down syndrome }(\mathrm{n}=2) \\
\text { Congenital heart disease }(\mathrm{n}=3) \\
\text { Congenital immunoglobulin A (IgA) deficiency }(\mathrm{n}=1) \\
\text { Premature rupture of the membranes }(\mathrm{n}=3) \\
\text { Low birth weight }(<2,500 \mathrm{~g})(\mathrm{n}=8) \\
\text { Patients with asthma }(\mathrm{n}=15) \\
\text { Total number (excluded babies) }(n=32)\end{array}$ \\
\hline \begin{tabular}{|l|l|} 
Number of participants included/followed up \\
$(n=379)$
\end{tabular} & $\begin{array}{l}\text { Number of participants lost in the follow up } \\
(n=109)\end{array}$ \\
\hline
\end{tabular}

TABLE 2. The comparison of infant feeding practices with number of infections diagnosed at $\leq 5$ years of age

\begin{tabular}{|c|c|c|c|c|c|}
\hline & \multirow[t]{2}{*}{$\mathbf{N}(\%)$} & \multicolumn{4}{|c|}{ Number of infections diagnosed at first five years of age (mean \pm SD) } \\
\hline & & $\begin{array}{l}\text { Respiratory tract } \\
\text { infections }\end{array}$ & $\begin{array}{c}\text { Acute } \\
\text { otitis media }\end{array}$ & $\begin{array}{c}\text { Acute } \\
\text { gastroenteritis }\end{array}$ & $\begin{array}{c}\text { Acute urinary } \\
\text { system infections }\end{array}$ \\
\hline \multicolumn{6}{|c|}{ Duration of exclusive breastfeeding } \\
\hline$\geq 6$ months & $157(58.15 \%)$ & $18.89 \pm 6.568$ & $1.57 \pm 1.016$ & $0.99 \pm 0.689$ & $2.25 \pm 0.985$ \\
\hline$<6$ months & $113(41.85 \%)$ & $19.73 \pm 6.059$ & $2.78 \pm 1.969$ & $2.78 \pm 1.522$ & $2.26 \pm 0.789$ \\
\hline$p$ & & 0.063 & 0.01 & 0.01 & 0.789 \\
\hline \multicolumn{6}{|c|}{ Duration of total breastfeeding } \\
\hline$\geq 12$ months & $193(71.48 \%)$ & $18.93 \pm 6.517$ & $1.31 \pm 0.717$ & $0.70 \pm 0.495$ & $2.29 \pm 0.765$ \\
\hline$<12$ months & $77(28.52 \%)$ & $21.36 \pm 5.669$ & $2.71 \pm 1.729$ & $2.93 \pm 1.403$ & $2.31 \pm 0.891$ \\
\hline$p$ & & 0.059 & 0.032 & 0.012 & 0.896 \\
\hline \multicolumn{6}{|l|}{ Ever breastfed } \\
\hline Yes & $253(93.70 \%)$ & $18.78 \pm 5.963$ & $1.45 \pm 0.569$ & $0.85 \pm 0.452$ & $2.12 \pm 0.887$ \\
\hline No & $17(6.30 \%)$ & $19.96 \pm 6.026$ & $2.89 \pm 1.632$ & $2.96 \pm 1.563$ & $2.32 \pm 0.658$ \\
\hline$p$ & & 0.112 & 0.012 & 0.014 & 0.856 \\
\hline
\end{tabular}


Long-term positive effect of breast milk against infections may be explained by the study conducted by Hasselbach et al. They measured the thymus index through ultrasound technique and found that infants who were breastfed exclusively for the first 4 months of life have larger thymus index when compared with those breastfed with baby formula. ${ }^{17}$ Jeppesenet al. showed that breastfeeding was in line with CD8 $\mathrm{T}$ cell increase rather than thymus enlargement only. ${ }^{18}$

In the study conducted by Kramer MS ${ }^{19}$ et al., an association between breast milk and decrease in morbidity and mortality due to gastrointestinal and respiratory tract infections was noted. In the present study, number of the cases with gastroenteritis in the children who were breastfed for more than 12 months was lower than those who were breastfed for less than 12 months $(\mathrm{p}<0.05)$. Since use of baby bottle and spoon were prevented for the infants who were exclusively breastfed during the first 6 months of life might have reduced the number of the cases of gastroenteritis. Another reason may be the fact that breast milk is rich in IgA which is the most important protective agent for intestines. ${ }^{20}$

We did not detect any association between acute respiratory tract infection and breast milk. There are different outcomes in the studies conducted on effect of breast milk for respiratory tract infections. For instance, Michiyo Yamakawa ${ }^{13}$ et al., did not find any association between breastfeeding and hospitalization due to respiratory tract infection in their study where 43,367 babies were monitored in 2015 . Furthermore, Ilse Tromp ${ }^{21}$ et al., revealed that respiratory tract infections until 4 years of age are less in the infants who were breastfed for more than 6 months in their study conducted in 2017. The reason for such difference may depend on the

TABLE 3. Demographic characteristics and duration of breastfeeding

\begin{tabular}{|c|c|c|c|c|}
\hline & \multicolumn{2}{|c|}{ Breastfeeding period } & \multirow[b]{2}{*}{ 6-11 months $N^{*}(\%)$} & \multirow[b]{2}{*}{$\geq 12$ months $\mathrm{N}^{*}(\%)$} \\
\hline & Never $\mathbf{N}^{*}(\%)$ & $<6$ months $\mathrm{N}^{*}(\%)$ & & \\
\hline \multicolumn{5}{|l|}{ Maternal characteristics } \\
\hline \multicolumn{5}{|l|}{ Maternal age } \\
\hline$\leq 25$ & $5(1.85 \%)$ & $8(2.96 \%)$ & $9(3.33 \%)$ & $68(25.19 \%)$ \\
\hline $26-35$ & $8(2.96 \%)$ & $16(5.93 \%)$ & $17(6.30 \%)$ & $82(30.37 \%)$ \\
\hline$\geq 36$ & $4(1.48 \%)$ & $4(1.48 \%)$ & $6(2.22 \%)$ & $43(15.93 \%)$ \\
\hline \multicolumn{5}{|l|}{ Educational status } \\
\hline Primary school & $10(3.70 \%)$ & $14(5.19 \%)$ & $16(5.93 \%)$ & $96(35.56 \%)$ \\
\hline Secondary-highschool & $5(1.85 \%)$ & $10(3.70 \%)$ & $12(4.44 \%)$ & $75(27.78 \%)$ \\
\hline University & $2(0.74 \%)$ & $4(1.48 \%)$ & $4(1.48 \%)$ & $22(8.15 \%)$ \\
\hline \multicolumn{5}{|c|}{ Ever received breastfeeding counseling? } \\
\hline Yes & $5(1.85 \%)$ & $18(6.67 \%)$ & $22(8.15 \%)$ & $136(50.37 \%)$ \\
\hline No & $12(4.44 \%)$ & $10(3.70 \%)$ & $10(3.70 \%)$ & $57(21.11 \%)$ \\
\hline \multicolumn{5}{|l|}{ Monthly income } \\
\hline$\leq 500 €$ & $7(2.59 \%)$ & $6(2.22 \%)$ & $7(2.59 \%)$ & $99(36.67 \%)$ \\
\hline $500-1000 €$ & $6(2.22 \%)$ & $14(5.19 \%)$ & $17(6.30 \%)$ & $78(28.89 \%)$ \\
\hline$>1000 €$ & $4(1.48 \%)$ & $8(2.96 \%)$ & $8(2.96 \%)$ & $16(5.93 \%)$ \\
\hline \multicolumn{5}{|l|}{ Child characteristics } \\
\hline \multicolumn{5}{|l|}{ Sex } \\
\hline Female & $9(3.33 \%)$ & $13(4.81 \%)$ & $15(5.56 \%)$ & $99(36.66 \%)$ \\
\hline Male & $8(2.96 \%)$ & $15(5.56 \%)$ & $17(6.30 \%)$ & $94(34.81 \%)$ \\
\hline \multicolumn{5}{|l|}{ Exposure to tobacco smoke? } \\
\hline Yes & $4(1.48 \%)$ & $6(2.22 \%)$ & $7(2.59 \%)$ & $37(13.70 \%)$ \\
\hline No & $13(4.81 \%)$ & $22(8.15 \%)$ & $25(9.26 \%)$ & $156(57.78 \%)$ \\
\hline \multicolumn{5}{|l|}{ Number of siblings } \\
\hline None & $2(0.74 \%)$ & $8(2.96 \%)$ & $9(3.33 \%)$ & $22(8.15 \%)$ \\
\hline 1 or 2 & $7(2.59 \%)$ & $10(3.70 \%)$ & $12(4.44 \%)$ & $99(36.67 \%)$ \\
\hline$>2$ & $8(2.96 \%)$ & $10(3.70 \%)$ & $11(4.07 \%)$ & $72(26.67 \%)$ \\
\hline \multicolumn{5}{|l|}{ Attendance to day nursery? } \\
\hline Yes & $9(3.33 \%)$ & $16(5.93 \%)$ & $18(6.67 \%)$ & $83(30.74 \%)$ \\
\hline No & $8(2.96 \%)$ & $12(4.44 \%)$ & $14(5.19 \%)$ & $110(40.74 \%)$ \\
\hline
\end{tabular}

* The percentages in the table represent the proportion of the total number of mothers and infants ( $\mathrm{n}=270$ participants). 
facts that acute respiratory tract infections have many subgroups and the cause may diversify as viral, bacterial or parasitary.

Otitis media accounts for at least 24 million clinic visits each year in United States and is the most common condition for which antibiotics are prescribed. ${ }^{22,23}$ Alho et al., mentioned importance of feeding status of the babies during first 3 months of life for persistent otitis media. ${ }^{24}$ Infants who were fed by baby formula and used baby bottle during the same period have an increased risk. Our findings suggested that otitis media was detected less in those who were only breastfed during the first 6 months of life and in those who were breastfed for 12 months or more.

Another common infection detected during childhood is urinary system infections. ${ }^{25}$ Although positive effect of breastfeeding against urinary system infections was reported in the literature, ${ }^{7,26}$ we did not find any relationship between exclusive breastfeeding and duration of total breastfeeding period and number of urinary system infections within 5 years. Ranjitha Katikaneni et al., did not detect any association between urinary tract infections observed during the first 3 months of life and breastfeeding status. ${ }^{27}$ They suggested that this result was due to the difference in sociodemographic characteristics of the infants as well as the mothers.

Strengths of the present study include the following: entering the infection diagnoses according to ICD coding system by the physicians and confirmation of such diagnoses by the researchers increased the reliability of the study. Another issue that adds value to the present study is personal interviews with parents within regular intervals for 5 years. The participants were encouraged about breastfeeding and the information provided by the mothers was confirmed during each monitoring visit and all follow-up visits were recorded by the same physician for 5 years.

The present study has some limitations; the infections we analyzed were only the ones which parents sought medical assistance and therefore recorded. The infections parents deemed simple and recovered easily may have caused recall bias. Another limitation is loss of 120 infants because of long term design of the study as 5 years; this may cause a bias on the results. And the infections events at first year of life included to study but how long babies would be breastfed wasn't clear yet at that time.

\section{CONCLUSION}

The present study where long-term benefits of the breastfeeding were investigated revealed a significant decrease in infections such as otitis media and gastroenteritis during the first 5 years of life with breastfeeding for 12 months or more.

Furthermore, we also detected that infections such as otitis media and gastroenteritis were significantly less common until five years of age in children who exclusively breastfed during the first 6 months.

\section{REFERENCES}

1. Lawrence RA, Lawrence RM. Breastfeeding: A Guide for the Medical Profession. $7^{\text {th }}$ ed. Maryland Heights, MO: Elsevier Mosby; 2011.

2. Eidelman A, Schanler RJ. Breastfeeding and theuse of human milk. Pediatrics 2012;129(3):e827-41.

3. World Health Organization. The optimal duration of exclusive breastfeeding: report of the expert consultation. Geneva, 2002. [Accessed on: Februrary 20, 2016]. Available at:http: / / www.who.int/ nutrition/publications / optimal_ duration_of_exc_bfeeding_review_eng.pdf

4. Jansen $\mathrm{MA}$, van den Heuvel D, van Zelm MC, et al. Decreased Memory B Cells and Increased CD8 Memory T Cells in Blood of Breastfed Children: The Generation R Study. PLoS One. 2015;10(5):e0126019.

5. Hanson LA. Breastfeeding provides passive and likely long-lasting active immunity. Ann Allergy Asthma Immunol 1998;81(6):523-33.

6. Hanson LA. The mother-off spring dyad and the immune system. Acta Paediatr 2000;89(3):252-8.

7. Oddy WH. Breastfeeding protects against illness and infection in infants and children: a review of the evidence. Breastfeeding Rev 2001;9(2):11-8.

8. Bachrach VR, Schwarz E, Bachrach LR. Breastfeeding and the risk of hospitalization for respiratory disease in infancy: a meta-analysis. Arch Pediatr Adolesc Med 2003;157(3):237-43.

9. Duijts L, Jaddoe VW, Hofman A, et al. Prolonged and exclusive breastfeeding reduces the risk of infectious diseases in infancy. Pediatrics 2010;126(1):e18-25.

10. World Health Organization. Causes of child mortality, 2000-2012. [Accessed on: Februrary 20, 2016]. Available at: http: / / www.who.int/gho/child_health/mortality / mortality_causes_region_text/en/

11. Biering-Sørensen S, Søndergaard G, Vitting Andersen $\mathrm{K}$, et al. Time trends in socio-economic factors and risk of hospitalisation with infectious diseases in pre-school children 1985-2004: ADanish register-based study. Paediatr Perinat Epidemiol 2012;26(3):226-35.

12. Spear HJ. Breastfeeding \& support. AWHONN Lifelines 2005;9(2):181-3.

13. Yamakawa M, Yorifuji T, Kato T, et al. Long-Term Effects of Breastfeeding on Children's Hospitalization for Respiratory Tract Infections and Diarrhea in Early Childhood in Japan. Matern Child Health J 2015;19(9):1956-65.

14. Hahn DL, Anttila T, Saikku P. Association of Chlamydia pneumoniae IgA antibodies with recently symptomatic asthma. Epidemiol Infect 1996;117(3):513-7.

15. Culley FJ, Pollott J, Openshaw PJ.Age at first viral infection determines the pattern of $\mathrm{T}$ cellmediated disease during reinfection in adulthood. J Exp Med 2002;196(10):1381-6.

16. Baydar Artantas A, Kayhan Tetis B, et al. Knowledge level, attitude and own experience of health professionals about 
breastfeeding and breast milk in a city of Turkey: Crosssectional study. Arch Argent Pediatr 2016;114(6):514-20.

17. Hasselbalch H, Jeppesen DL, Engelmann MD, et al. Decreased thymus size in formula-fed infants compared with breastfed infants. Acta Paediatr 1996;85(9):1029-32.

18. Jeppesen DL, Hasselbalch H, Lisse IM, et al. T-lymphocyte subsets, thymic size and breastfeeding in infancy. Pediatr Allergy Immunol 2004;15(2):127-32.

19. Kramer MS, Kakuma R. Optimal duration of exclusive breastfeeding. Cochrane Database Syst Rev 2012;(8):CD003517.

20. Field CJ. The immunological components of human milk and their effect on immune development in infants. J Nutr 2005;135(1):1-4.

21. Tromp I, Kiefte-de Jong J, Raat H, et al. Breastfeeding and the risk of respiratory tract infections after infancy: The Generation R Study. PloS One 2017;12(2):e0172763.

22. Auinger P, Lanphear BP, Kalkwarf HJ, et al. Trends in otitis media among children in the United States. Pediatrics 2003;112(3 pt 1):514-20.

23. Grijalva CG, Nuorti JP, Griffin MR. Antibiotic prescription rates for acute respiratory tract infections in US ambulatory settings. JAMA 2009;302(7):758-66.

24. Alho OP, Kilkku O, Oja H, et al. Control of the temporal aspect when considering risk factors for acute otitis media. Arch Otolaryngol Head Neck Surg 1993;119(4):444-9.

25. Hoberman A, Wald ER. Urinary tract infections in young febrile children. Pediatr Infect Dis J 1997;16(1):11-7.

26. Hanson LA. Protective effects of breastfeeding against urinary tract infection. Acta Paediatr 2004;93(2):154-6.

27. Katikaneni R, Ponnapakkam T, Ponnapakkam A, et al. Breastfeeding does not protect against urinary tract infection in the first 3 months of life, but vitamin D supplementation increases the risk by $76 \%$. Clin Pediatr (Phila) 2009;48(7):750-5. 